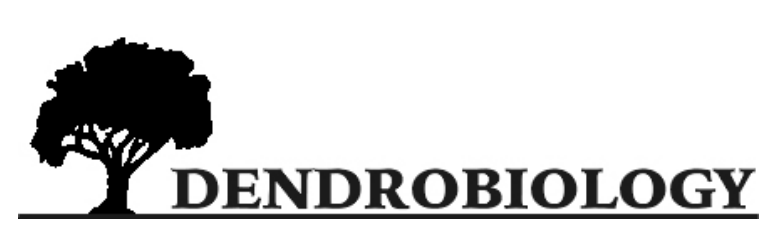

2020, vol. 84, 30-38

https://doi.org/10.12657/denbio.084.003

\author{
Xiongwen Chen, Dale G. Brockway, Qinfeng Guo
}

\title{
Temporal patterns of pollen shedding for longleaf pine (Pinus palustris) at the Escambia Experimental Forest in Alabama, USA
}

Received:17 June 2020; Accepted: 6 November 2020

\begin{abstract}
Longleaf pine is an important tree species in the southeastern United States and studying the temporal patterns of pollen shedding is crucial to a better understanding of its phenology and seed production. In this study, field observation data on the timing of pollen shedding from 1958 to 2013 were analyzed with reference to local weather conditions. Our results indicated that the time of peak pollen shedding after January 1 (TPPS) ranged from 53 days (about February 22) to 95 days (around April 5). There was no significant trend of decreasing TPPS. The number of days with the maximum air temperature above $0{ }^{\circ} \mathrm{C}$ was close to the TPPS. The accumulated maximum daily air temperature for the TPPS approximated an average of $1,342{ }^{\circ} \mathrm{C}$. The TPPS declined with an increase in the average air temperature during winters. The time of $80 \%$ accumulated pollen density (TAPD) varied from 5 to 32 days, with an average of 13 days. Taylor's power-law was evident in the TAPD data, with the time group of 10-15 days having an interval time of 2 years. Winter weather was not correlated with the TAPD. These results provide new information concerning the pollen phenology for longleaf pine trees.
\end{abstract}

Keywords: accumulated air temperature, accumulated pollen density, peak pollen shedding, pollen phenology, power-law

Addresses: X. Chen, Department of Biological and Environmental Sciences, Alabama A \& M University, Normal, AL 35762, USA, e-mail: xiongwen.chen@aamu.edu

D. G. Brockway, USDA Forest Service, Southern Research Station, 521 Devall Drive, Auburn, AL 36849, USA

Q. Guo, USDA Forest Service, Eastern Forest Environmental Threat Assessment Center,

Research Triangle Park, NC 27709, USA

\section{Introduction}

Pollen releasing, fertilization, and seed production are critical steps in the reproduction processes of trees. Pollen dispersal is one of the most important processes that affect the genetic composition of tree populations. It has been suggested that pollen hybridization between sister species and introgression promote species adaptation to extreme environments for many taxa (Baskett \& Gomulkiewicz,
2011), and can effectively reduce variation among tree populations (Rusanen et al., 2003). Extending the time interval of pollen dispersal may improve the effectiveness of pollination and hence seed production. However, such an increase might become problematic for human health, in that airborne pollen can contribute to air pollution and respiratory allergies (e.g., rhinitis, asthma, and skin rash), especially in urban and industrialized areas (Pawankar et al., 2013; Schmidt, 2016; Oduber et al., 2019). In 
developed countries, about $15-30 \%$ of the population is affected by pollen-induced allergies (Aas et al., 1997). The severity of allergy symptoms depends on the tree species and the sensitivity of different people to these allergens (Damialis et al., 2019). Shortening the time interval of pollen dispersal may contribute to improving public health. However, increasing evidence indicates that climate change is affecting the timing of the pollen shedding season (Ziska et al., 2011; Bonofiglio et al., 2013).

The beginning, peak discharge, and cessation of a pollen shedding time interval depend on the phenology of its species, but it may also be influenced by weather conditions. Airborne pollen is considered to be a sensitive indicator of plant response to climate change (Clot, 2003; Oteros et al., 2015; D'Amato et al., 2016). As the global climate has continued to change, tree leaf-out time in the northern hemisphere has advanced about 4-5 days per decade on average since the 1980s (Xu et al., 2020). It is possible that pollen phenology for some trees has been changed. Many tree species show adaptation to the length of the frost-free growing season (Frewen et al., 2000); while for some trees, spring heat accumulation determines the phenology of bud burst and flowering, such as for white birches (Rousi et al., 2011; Rousi \& Heinonen, 2007). The spring phenology of silver birch is driven by the heat sum as growing degree days with a $5{ }^{\circ} \mathrm{C}$ threshold (Rousi et al., 2019), which is commonly used to evaluate phenology. However, the critical variables for inducing pollen shedding and flowering can vary among different species and their habitat environments (Kelly \& Sork, 2002; Kon \& Noda, 2007). Some studies of pollen season reported an earlier onset (Orlandi et al., 2010) and an extended period of shedding (De Linares et al., 2017), while others revealed the opposite (Bogawski et al., 2014). Thus, it is necessary to study the pollen phenology (i.e., temporal dynamics of pollen development and release) of important tree species in their local environment.

Longleaf pine (Pinus palustris Mill.) forests were historically among the most important ecosystems in the southeastern United States, because of their ecological and economic value (Brockway et al., 2006). But following extensive exploitation and land use conversion during the 19th and 20th centuries, longleaf pine forests are now among the most endangered ecosystems in the United States (Noss et al., 1995). The extent of longleaf forest ecosystems has been reduced dramatically, to less than $5 \%$ of their original occupancy (Frost, 2006). The sporadic seed production of longleaf pine trees also led to this decline and limited the natural regeneration and seedling production efforts that can contribute to their restoration (Brockway et al., 2006). This irregular seed production is thought to be related to the complex interactions between climate fluctuation and their reproduction processes (Chen et al., 2016, 2018; Guo et al., 2016), such as limited pollen production and the male-female sex allocation (Guo et al., 2017).

After analysis of hourly air temperature and data from field observations of pollen shedding time at the Escambia Experimental Forest from 1957 to 1966, Boyer (1973) found that January 1 was the starting date for accumulating heat sum and $50^{\circ} \mathrm{F}\left(10^{\circ} \mathrm{C}\right)$ was the threshold of air temperature, which minimized annual variations in heat sums for pollen shedding. From 1958 to 2013, the time of peak pollen shedding after January 1 (TPPS) and time of $80 \%$ pollen accumulated density (TPAD) were recorded at the Escambia Experimental Forest by research scientists from the USDA Forest Service. Information on hourly air temperature was difficult to obtain, but the daily maximum and minimum air temperatures were easily accessed from weather station records. Because of the strengths and limitations of previous approaches (e.g., Chuine \& Régnière, 2017), a simple or alternative way is needed to describe pollen phenology and to discern any scaling relationships presented in the long term data. A related hypothesis to consider is that the pollen shedding time of longleaf pine may have changed during the last several decades as a result of climate change. The goal of this study is to characterize the temporal patterns in pollen shedding based on long-term field observations performed annually on a longleaf pine forest. Our objectives are (i) to compare the time series of pollen shedding and to identify an indicator (other than degree-hours) related to pollen releases, such as for TPPS and TAPD; (ii) to characterize the dynamics of TPPS and TAPD; and (iii) to evaluate how winter weather conditions affect TPPS and TAPD, and whether there existed a climate change-driven trend in the TPPS and TAPD at this experimental forest. Results should provide a better understanding of the pollen shedding processes and the effect of local weather conditions on pollen discharge in longleaf pine trees.

\section{Material and Methods}

\section{Study site}

Observations of pollen phenology for longleaf pine trees were conducted by scientists of the USDA Forest Service from 1957 to 2013 at the Escambia Experimental Forest. This site is located about $11 \mathrm{~km}$ south of Brewton, Alabama, USA $\left(31^{\circ} 13^{\prime} \mathrm{N}\right.$, $\left.87^{\circ} 16^{\prime} \mathrm{W}\right)$. When field observations began in 1957 , trees were about 50 years old. The average diameter at breast height was more than $20 \mathrm{~cm}$ and the mean tree height around $24 \mathrm{~m}$. The local climate is temperate subtropical with long, hot, and humid summers. 
The annual mean daily temperatures range from 16 to $23^{\circ} \mathrm{C}$ and annual precipitation is $1090-1750 \mathrm{~mm}$ based on data from the local weather station (Boyer, 1973). The soil types are sandy loams and loamy sands. The understory plant community is mainly composed of grasses, forbs, shrubs, and tree seedlings, which are affected by prescribed burning that is applied once every three years (Boyer, 1973; Guo et al., 2017).

\section{Longleaf pine pollen monitoring}

Pollen traps, which consisted of aluminum slides with open cells and a stable tape fixed inside for pollen to adhere (Grano, 1958), were set up at a weather instrument shelter in a longleaf pine forest during the period of pollen shedding (typically mid-February through early April). Traps were changed three times per week, yielding a total of 24 traps, having the same length of time for exposure. The time interval of exposure (i.e., beginning and ending date and time) for each slide was recorded. The density of longleaf pine pollen deposited on each trap was determined by counting the number of pollen grains under a $100 \times$ microscope for ten systematically distributed fields per trap (Boyer, 1973). Longleaf pine pollen grains (55-60 $\mu \mathrm{m}$ in diameter) could be clearly distinguished from other species. Pollen counts were then converted to the average number of pollen grains per $\mathrm{cm}^{2}$ (Guo et al., 2017). These data were used to establish the TPPS, accumulated pollen density during the monitoring period, and the TAPD.

\section{Data processing and methods}

In this study, two points in time were of major interest, TPPS, and TAPD. Determination of the starting date is defined as when the running mean of 5 days reaches $1 \%$ of the total amount of pollen shed (Mullenders, 1974), but the annual sum is not known until the season is over. Most often, the course of the pollen count rises quite steeply, reaching slightly different threshold values on the same day.

The daily maximum and minimum air temperatures from 1978 to 2013 were obtained from the nearby weather station. Growing degree day and the modified forms (MGDD) are often used to characterize tree phenology, but different tree species may have different thresholds. Here an MGDD was used. MGDD0, MGDD5, and MGDD10 represent the number of days having the daily maximum air temperature above $0{ }^{\circ} \mathrm{C}, 5{ }^{\circ} \mathrm{C}$, and $10{ }^{\circ} \mathrm{C}$, respectively. The accumulated daily maximum air temperature was calculated as the sum of daily maximum air temperature data. The average air temperature during January, February, and March was calculated from daily maximum and minimum air temperature data.
The TAPD, an index describing pollen accumulation through time, was evenly classified into four groups based on the values in order to estimate the frequency for each group, which include 5-10 days, 10-15 days, 15-20 days, and above 20 days. The interval year(s) of each group along the entire TAPD time series was counted and the average was estimated.

Taylor (1961) discovered an empirical law in ecology, which links the variance of the population for a species in a habitat area to its corresponding mean by a power-law relationship. This scaling relationship has been expanded from population density and widely observed in ecology (e.g., Cohen et al., 2013; Taylor, 2019), such as pollination success in a shrub species at Mexico's Yucatan Peninsula (Arceo-Gómez et al., 2016). Our recent studies indicated that some plants followed Taylor's law in their growth traits (Chen et al., 2017; Chen, 2020; Chen \& Chen, 2020), but it was not tested in pollen shedding. In this study, Taylor's power-law can be expressed in the following equation:

$$
\begin{gathered}
\text { Variance }=a \times \text { Mean }^{r} \\
\log (\text { Variance })=\log (a)+r \times \log (\text { Mean }) .
\end{gathered}
$$

Where Variance stands for the variance of pollen shedding time (TPPS or TAPD) at different years, Mean as the average time, $r$ is the slope of the fitting line, and $\log (a)$ is the intercept. With the time increase of one year from 1958 to 2013, the average and variance of pollen shedding time at different periods (such as from 1958 to $1959,1960 \ldots$ and 2013, respectively) was estimated (Chen et al., 2017). r was estimated from the correlation between log (mean) and $\log$ (variance). Spearman's correlation was conducted by SAS software (Version 9.3, SAS Institute Inc., Cary, NC, USA) with the statistical significance at $p<0.05$.

\section{Results}

The TPPS ranged from 53 days (about February 22 ) to 95 days (around April 5), and the average time was 76 days (around March 17) (Fig. 1a). The decreasing trend of TPPS through time was not significant $(p>0.05)$. The coefficient of variation (CV) for the TPPS had two domains (before 1975 and after 1975) (Fig. 1b). The CVs decreased and tended to be stable through time.

Comparing the TPPS with the modified growing degree day, but with the maximum air temperature above $0{ }^{\circ} \mathrm{C}, 5{ }^{\circ} \mathrm{C}$, and $10{ }^{\circ} \mathrm{C}$ (MGDD0, MGDD5, and MGDD10), MGDD0 was very close to the value of TPPS $\left(\mathrm{R}^{2}=0.9999, \mathrm{p}<0.01\right)$ (Fig. 2$)$. 

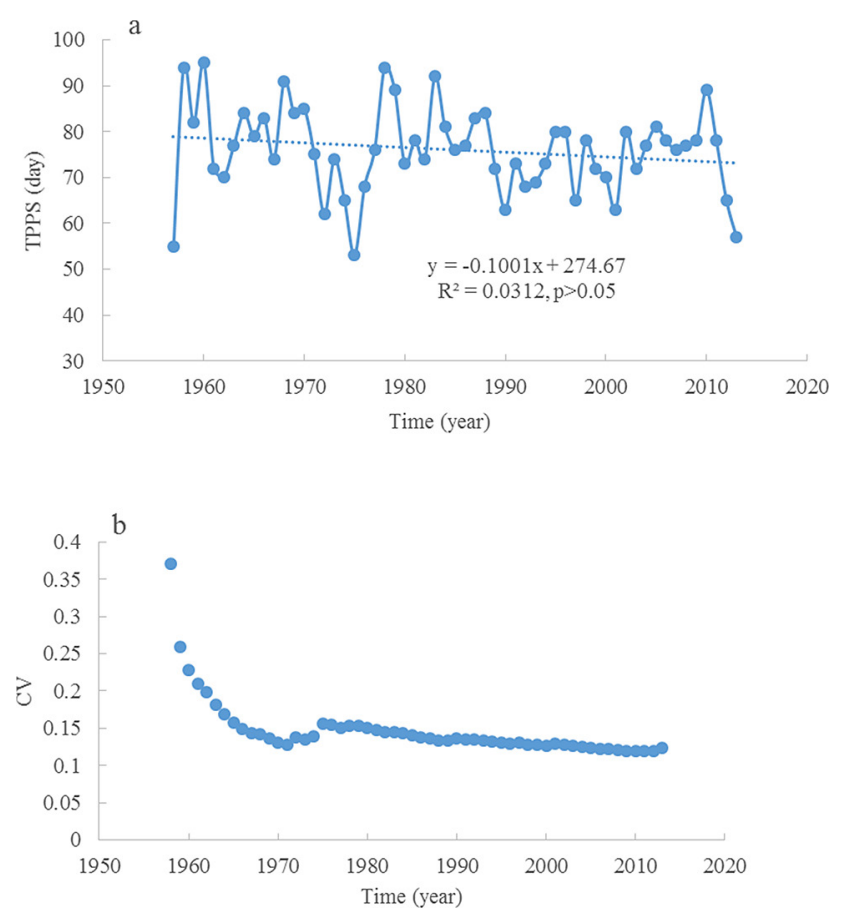

Fig. 1. Temporal dynamics of the time of peak pollen shedding (TPPS) from 1958 to 2013 (a) and the coefficients of variation (CVs) (b)

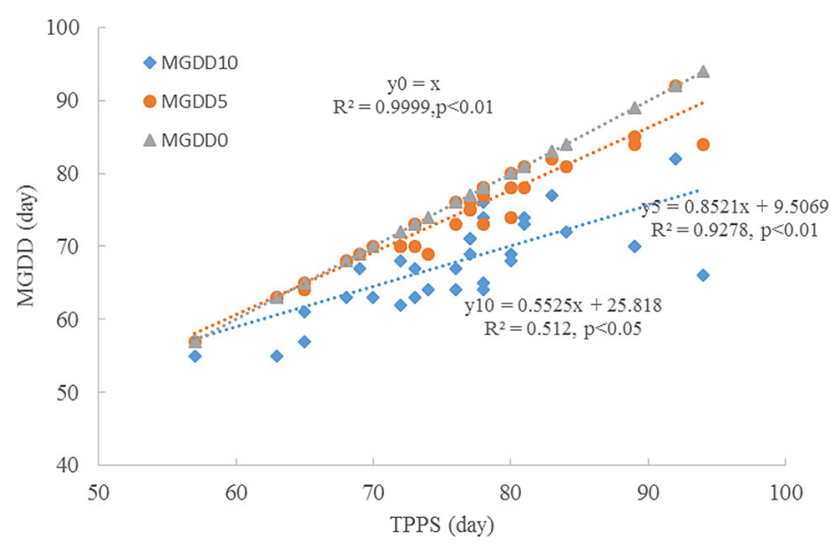

Fig. 2. Correlation between the annual time of peak pollen shedding (TPPS) from 1958 to 2013 and the Modified Growing-Degree-Day (MGDD) with the maximum air temperature above $0{ }^{\circ} \mathrm{C}, 5{ }^{\circ} \mathrm{C}$, and $10{ }^{\circ} \mathrm{C}$ (MGDD0, MGDD5, and MGDD10) (y0, y5, and y10 represent MGDD0, MGDD5, and MGDD10 in the equations, respectively)

The accumulated daily maximum air temperatures for the TPPS ranged from $1,027^{\circ} \mathrm{C}$ to $1,522^{\circ} \mathrm{C}$, with an average of $1,342{ }^{\circ} \mathrm{C}$ (Fig. 3). The average value can be used to estimate the possible time of pollen peak without the detailed data for hourly air temperature. Taylor's power-law for the TPPS at different times was not significant ( $p>0.05)$. Generally, the TPPS declined (i.e., arrived sooner during the year) with an increase in the average air temperature in January, February, and March (Fig. 4) ( $<$ $0.05)$. The correlation between TPPS and rainy days

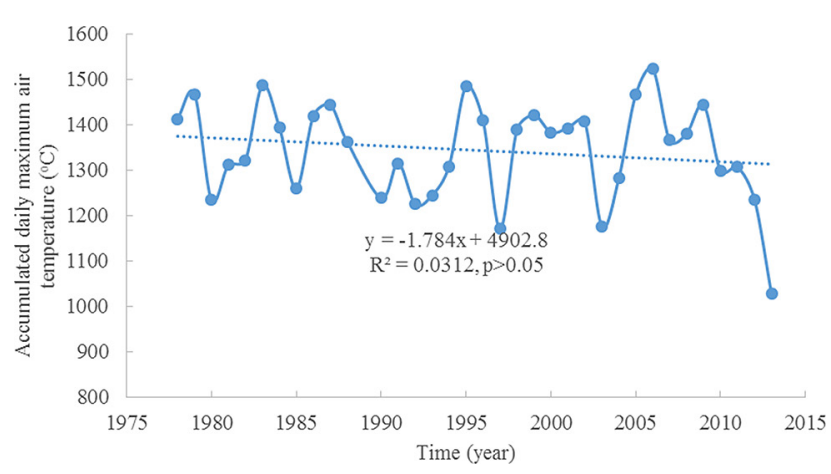

Fig. 3. Accumulated maximum daily air temperatures for the time of peak pollen shedding (TPPS) from 1978 to 2013

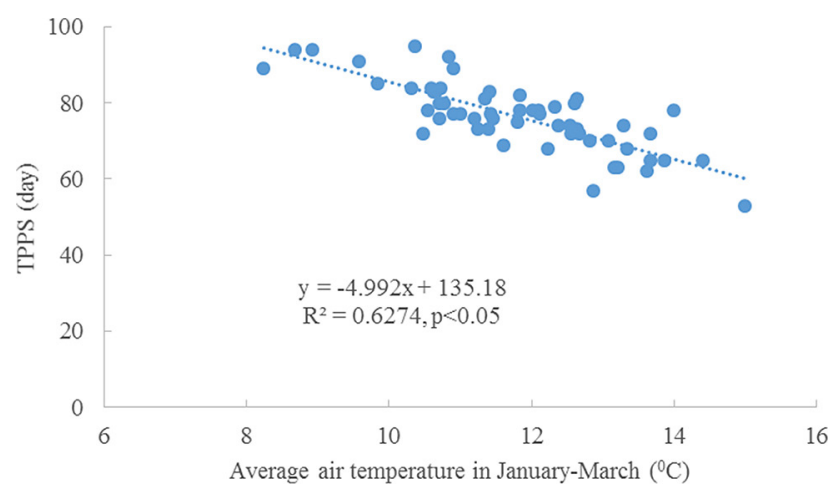

Fig. 4. Correlation between the time of peak pollen shedding (TPPS) and the average air temperature in January, February, and March

in January, February, and March was not significant $(\mathrm{p}>0.05)$.

The TAPD varied from 5 days in 1977 to 32 days in 2013, with the average at about 13 days (Fig. 5a). A general trend in TAPD through time was not apparent. Most TAPD values occurred within 10-15 days (44\%), followed by $5-10$ days (31\%) (Fig. $5 \mathrm{~b})$. The coefficient of variation was stable through time at 0.35 (Fig. 5c). Taylor's power-law for TAPD (log(average) and $\log ($ variance $)$ ) was significant $(p<0.05)$ (Fig. 5d). The time group of 10-15 days had the lowest interval time, about two years (Fig. 5e). Neither average air temperature (during January-March) nor TPPS was correlated with TAPD, respectively.

\section{Discussion}

Long-term observation of airborne pollen in longleaf pine forest affords a better opportunity to study the patterns of pollen phenology, because short-term periods of observation may provide limited data that constrains our ability to elucidate and understand the dynamic ecological processes operating at greater scales (Guo et al., 2016). Based on these 55 years of observation data for TPPS, a range of peak pollen shedding times was found, fluctuating from as short 

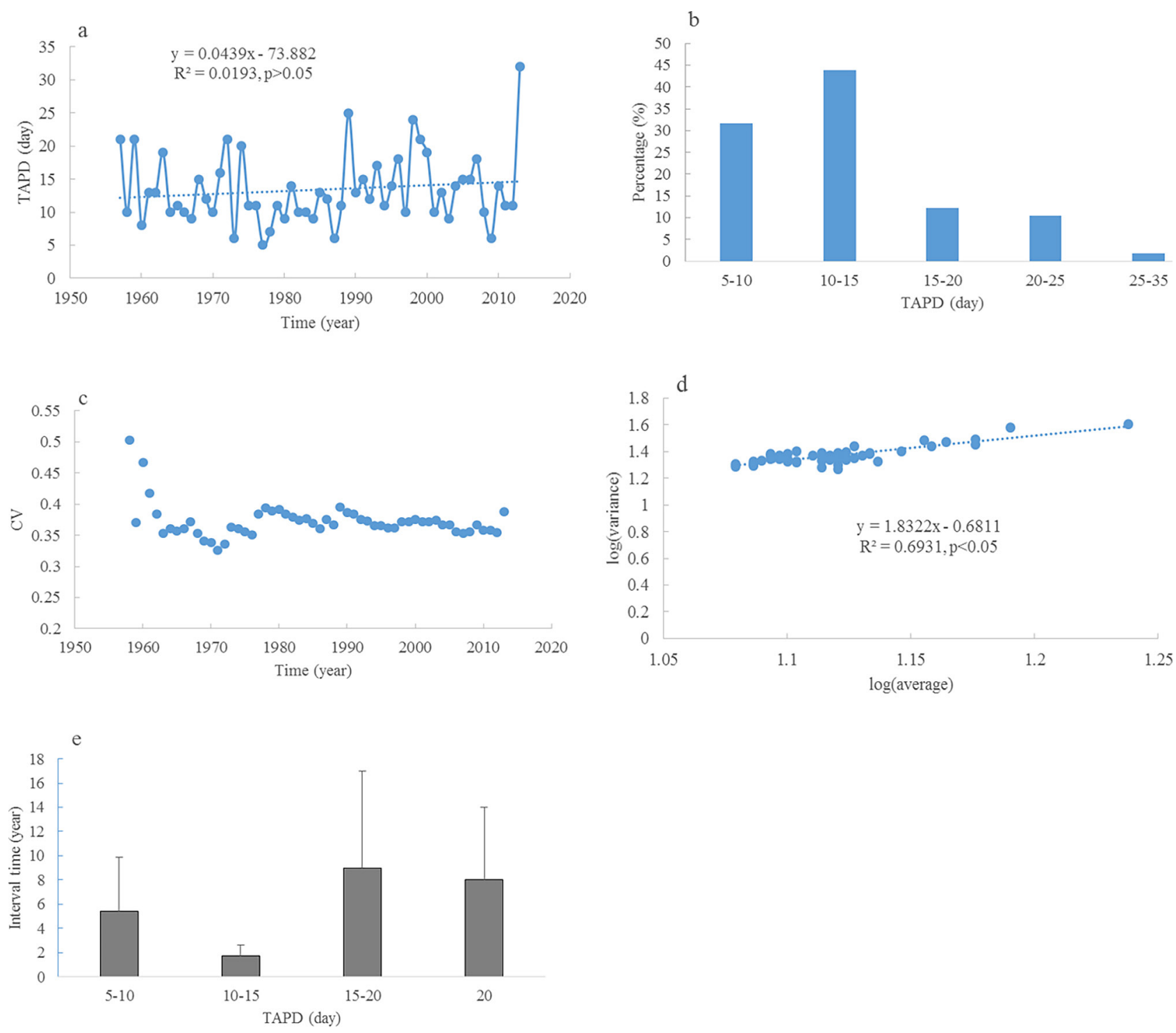

Fig. 5. Dynamics of the time of accumulated pollen density (TAPD) from 1958 to 2013 (a); the percentage of different groups of TAPD (b); the dynamics of CVs for TAPD through time (c); Taylor's power-law for TAPD (d); the interval times for different TAPD (e)

as 53 days (around February 22) to as long as 95 days (around April 5) following January 1. This range very closely approximates that reported by Boyer (1973), which indicated a range from February 23 to April 3, based on data from the first eight years of observation. After nearly five decades, the difference in these two range estimates was only 1-2 days. Although the range for TPPS did not change dramatically during those five decades, a phase-shift (before and after 1975) was detected in the dynamics of the CVs. Similar to the results from Emberlin et al. (2007) for other plants from a different region, there was no systematic earlier onset and no significant trend in TPPS for longleaf pine trees.

The annual change in TPPS appeared to be related to heat accumulation. Boyer (1973) analyzed the annual variation in TPPS by using January 1 as a starting date and $50{ }^{\circ} \mathrm{F}$ as an air temperature threshold.
But here, it was found that the modified growing degree days with the maximum air temperature of $0{ }^{\circ} \mathrm{C}\left(32^{\circ} \mathrm{F}\right)$ are close to the days of the annual TPPS. Also, it is more convenient to use a daily maximum air temperature of $0{ }^{\circ} \mathrm{C}$ to count the modified growing degree days, rather than the degree-hour heat sum above $50{ }^{\circ} \mathrm{F}$. This new method can serve as a more efficient alternative way to estimate annual TPPS for longleaf pine trees, with comparable accuracy. Similarly, Zhang et al. (2015) considered the accumulated growing degree days as an indicator for predicting the onset and duration of the pollen shedding season in the U.S.

Consistent patterns existed for the TPPS, even with the increase of tree ages through time. This result is consistent with previous studies, indicating that pollen shedding is related to heat (or energy) accumulation. Boyer (1973) reported that longleaf 
pines in southwestern Alabama need an average of 11,341 degree-hours (above $50^{\circ} \mathrm{F}$ ) after January 1 for peak pollen shedding. In this study, the accumulated maximum daily air temperatures above $0{ }^{\circ} \mathrm{C}$ after January 1 ranged from $1,027^{\circ} \mathrm{C}$ to $1,522^{\circ} \mathrm{C}$, with an average of $1,342{ }^{\circ} \mathrm{C}$. Fluctuation in the annual TPPS may be related to energy accumulation during temperature fluctuations, as illustrated with the maximum air temperature data used here. Winter weather can affect the time required to reach the peak of pollen shedding. Higher air temperatures in winter can shorten this period, such as when the warm temperatures during January and February (average $13.4^{\circ} \mathrm{C}$ ) in 1975 reduced the TPPS to 53 days (Fig. 4). Conversely, the low temperatures (average $10.3{ }^{\circ} \mathrm{C}$ ) during January, February, and March of 1960 extended the TPPS to 95 days. However, not all tree species follow such a pattern. Populus in southern Hungary was found to extend its pollen season during a warm and dry period, while in León, an extension of the flowering season for Populus was favored by low temperatures (Makra et al., 2012). The insignificant finding for Taylor's power law in TPPS through time may indicate that TPPS is not mainly controlled by a biological process. The observed variation is likely related to factors, such as differences in tree growth influenced by weather conditions, including temperature, precipitation, and wind (Garcia-Mozo et al., 2007; Rojo et al., 2015). The correlation between TPPS and rainy days in January-March was not significant. For individual trees, phenology is usually unpredictable, in that each is characterized by a unique genetic composition, age, and size, and responds individually to its ambient microclimate (Fotiou et al., 2011).

Although the TAPD also changed every year, a general trend during the past five decades was not in evidence. These results did not support the hypothesis of a more extended pollen season through time with rising global air temperatures (De Linares et al., 2017). A year with an extended period was usually followed by a year with a short period. But, the CVs were stable and were close to 0.35 . Here no correlation was observed between the annual TPPS and TAPD. Our results from longleaf pine forest did not support earlier (or later) endings and shorter pollen seasons, as reported by Cariñanos et al. (2014) for other plants in Spain. In contrast to TPPS, the relationship between the TAPD and the winter air temperature (average air temperature during January, February, and March) was not significant ( $>0.05)$. This means the relationship between winter air temperature and the annual TAPD might be complicated.

Although frost may affect the timing of pollen release (Andersen, 1991), pollen shedding is mainly a biological process. It is characterized by self-organization in pollen reproduction (Chen et al., 2020), validated by our significant finding for
Taylor's power-law (Fig. 5d). When considering possible causes of the cyclic rhythms in the flowering of plants, some theories and hypotheses regard physiological factors inherent within the plants to be of greater importance than external meteorological influences (Spieksma et al., 1995).

\section{Conclusion}

Analysis of long-term data on the pollen shedding process for longleaf pine trees revealed some clear temporal patterns related to pollen phenology. Annual TPPS was mainly associated with heat accumulation following January 1 , which can be described by the accumulated days with the maximum air temperature above $0{ }^{\circ} \mathrm{C}$. Thus, the time of peak pollen shedding appears to be driven by external meteorological factors in the ambient environment. The time of accumulated pollen density (to $80 \%$ of the total shed) is controlled primarily by biological factors within individual trees. Neither TPPS nor TAPD changed significantly during the 55 years influenced by climate fluctuation. However, it should be noted that seed production and ultimately the sustainability of the longleaf pine forest ecosystem is influenced by multiple physical factors and complex ecological processes, such as pollen production, pollen release from catkins, timing, and duration of pollen shedding, and direction of pollen dispersal in the air. These processes may be controlled by various meteorological factors. Further research is required to more completely understand how these physical factors interact with physiological processes in longleaf pines, at different developmental stages (e.g., strobili formation, catkin development, pollen maturation), during different seasons of the year, and environmental influences, such as air temperature (mean, maximum, minimum), precipitation (quantity, duration), light (radiation, day length), wind speed, and atmospheric turbulence. Most importantly, studies of tree phenology will bear the most useful fruit when conducted through long-term intensive and systematic field observations.

\section{Acknowledgment}

This study was partially supported by the USDA Mc-Stennis program (1008643).

\section{References}

Aas K, Aberg N, Bachert C, Bergmann K, Bergmann R \& Bonini S (1997) Allergic disease as a public health problem in Europe. European Allergy White Paper 1-46. 
Arceo-Gómez G, Alonso C, Abdala-Roberts L \& Parra-Tabla V (2016) Patterns and sources of variation in pollen deposition and pollen tube formation in flowers of the endemic monoecious shrub Cnidoscolus souzae (Euphorbiaceae). Plant Biology 18: 594-600. doi:10.1111/plb.12445.

Andersen TB (1991) A model to predict the beginning of the pollen season. Grana 30: 269-275. doi:10.1080/00173139109427810.

Baskett ML \& Gomulkiewicz R (2011) Introgressive hybridization as a mechanism for species rescue. Theoretical Ecology 4: 223-239. doi:10.1007/ s12080-011-0118-0.

Bogawski P, Grewling L, Nowak M, Smith M \& Jackowiak B (2014) Trends in atmospheric concentrations of weed pollen in the context of recent climate warming in Poznan (western Poland). International Journal of Biometeorology 58: 17591768. doi:10.1007/s00484-013-0781-5.

Bonofiglio T, Orlandi F, Ruga L, Romano B \& Fornaciari M (2013) Climate change impact on the olive pollen season in Mediterranean areas of Italy: air quality in late spring from an allergenic point of view. Environmental Monitoring and Assessment 185: 877-890. doi:10.1007/s10661-012-2598-9.

Boyer WD (1973) Air temperature, heat sums, and pollen shedding phenology of longleaf pine. Ecology 54: 420-426.

Brockway DG, Outcalt KW \& Boyer WD (2006) Longleaf pine regeneration ecology and methods: The longleaf pine ecosystem: Ecology, silviculture, and restoration (ed. by S Jose, EJ Jokela \& DL Miller) Springer, New York, pp. 95-133.

Cariñanos P, Alcázar P, Galán C \& Domínguez E (2014) Environmental behaviour of airborne Amaranthaceae pollen in the southern part of the Iberian Peninsula, and its role in future climate scenarios. Science of the Total Environment 470-471: 480-487. doi:10.1016/j.scitotenv.2013.10.024.

Chen X (2020) Variations in patterns of internode and branch lengths for several bamboo species. Plant Biosystems. (in press) doi:10.1080/112635 04.2020.1829729.

Chen X \& Chen X (2020) Variation of fruit size and its frequency distribution in Chinese Torreya. International Journal of Fruit Science. (in press) doi :10.1080/15538362.2020.1802395.

Chen X, Brockway DG \& Guo Q (2018) Characterizing the dynamics of cone production for longleaf pine forests in the southeastern United States. Forest Ecology and Management 429: 1-6. doi:10.1016/j.foreco.2018.06.014.

Chen X, Brockway DG \& Guo Q (2020) Burstiness of seed production in longleaf pine and Chinese Torreya. Journal of Sustainable Forestry. (in press) do i:10.1080/10549811.2020.1746914.
Chen X, Guo Q \& Brockway DG (2016) Analyzing the complexity of cone production in longleaf pine by multiscale entropy. Journal of Sustainable Forestry 35: 172-182. doi:10.1080/10549811.20 15.1135294.

Chen X, Guo Q \& Brockway DG (2017) Power laws in cone production of longleaf pine across its native range in the United States. Sustainable Agricultural Research 4: 64-73. doi:10.5539/sar. v6n4p64.

Chuine I \& Régnière J (2017) Process-based models of phenology for plants and animals. Annual Review of Ecology, Evolution, and Systematics 48: 159-182. doi:10.1146/annurev-ecolsys-110316-022706.

Clot B (2003) Trends in airborne pollen: an overview of 21 years of data in Neuchâtel (Switzerland). Aerobiologia (Bologna) 19: 227-234. doi:10.1023/B:AERO.0000006572.53105.17.

Cohen JE, Xu M \& Schuster WSF (2012) Allometric scaling of population variance with mean body size is predicted from Taylor's law and density-mass allometry. Proceedings of National Academy of Sciences USA 109: 15829-15834. doi:10.1073/ pnas.1212883109.

D'Amato G, Vitale C, Lanza M, Molino A \& D'amato $M$ (2016) Climate change, air pollution, and allergic respiratory diseases: an update. Current Opinion in Allergy and Clinical Immunology 16: 434-440. doi:10.1097/ACI.0000000000000301.

Damialis A, Häring F, Gökkaya M, Rauer D, Reiger M, Bezold S, Bounas-Pyrros N, Eyerich K, Todorova A, Hammel G, Gilles S \& Traidl-Hoffmann C (2019) Human exposure to airborne pollen and relationships with symptoms and immune responses: indoors versus outdoors, circadian patterns and meteorological effects in alpine and urban environments. Science of the Total Environment 653: 190-199. doi:10.1016/j.scitotenv.2018.10.366.

De Linares C, Delgado R, Aira MJ, Alcázar P, Alonso-Pérez S, Boi M, Carinanos P, Cuevas E, de la Guardia CD, Elvira-Rendueles B, Ferandez-Gonzalez D, Galan C, Gutierrez-Bustillo AM, Perez-Badia R, Rodriguez-Rajo FJ, Ruiz-Valenzuela L, Tormo-Molina R, Trigo MDM, Valencia-Barrera RM, Valle A \& Belmonte J (2017) Changes in the Mediterranean pine forest: pollination patterns and annual trends of airborne pollen. Aerobiologia 33: 375-391. doi:10.1007/s10453-017-9476-4.

Emberlin J, Smith M, Close R \& Adams-Groom B (2007) Changes in the pollen seasons of the early flowering trees Alnus spp. and Corylus spp. in Worcester, United Kingdom, 1996-2005. International Journal of Biometeorology 51: 181-191. doi:10.1007/s00484-006-0059-2. 
Fotiou C, Damialis A, Krigas N, Halley JM \& Vokou D (2011) Parietaria judaica flowering phenology, pollen production, viability and atmospheric circulation, and expansive ability in the urban environment: impacts of environmental factors. International Journal of Biometeorology 55: 35-50. doi:10.1007/s00484-010-0307-3.

Frewen BE, Chen THH, Howe GT, Davis J, Rohde A, Boerjan W \& Bradshaw HD Jr (2000) Quantitative trait loci and candidate gene mapping of bud set and bud flush in Populus. Genetics 154: 837-845.

Frost CC (2006) History and future of the longleaf pine ecosystem. The longleaf pine ecosystem: Ecology, silviculture, and restoration (ed. by $S$ Jose, EJ Jokela \& DL Miller) Springer, New York, pp. 9-42.

Garcia-Mozo H, Gómez-Casero MT, Domínguez E \& Galán C (2007) Influence of pollen emission and weather-related factors on variations in holm-oak (Quercus ilex subsp. ballota) acorn production. Environmental and Experimental Botany 61: 35-40.

Grano CX (1958) A timesaving slide for trapping atmospheric pollen. Forest Science 4: 94-95.

Guo Q, Brockway DG \& Chen X (2017) Temperature-related sex allocation shifts in a recovering keystone species, Pinus palustris. Plant Ecology and Diversity 10: 303-310. doi:10.1080/175508 74.2017.1402968.

Guo Q, Zarnoch SJ, Chen X \& Brockway DG (2016) Life cycle and masting of a recovering keystone indicator species under climate fluctuation. Ecosystem Health and Sustainability 2: e01226. doi:10.1002/ehs2.1226.

Kelly D \& Sork VL (2002) Mast seeding in perennial plants: why, how, where? Annual Review of Ecology and Systematics 33: 427-447. doi:10.1146/ annurev.ecolsys.33.020602.095433.

Kon H \& Noda T (2007) Experimental investigation on weather cues for mast seeding of Fagus crenata. Ecological Research 22: 802-806. doi:10.1007/ s11284-006-0320-5.

Makra L, Matyasovszky I, Páldy A \& Deák ÁJ (2012) The influence of extreme high and low temperatures and precipitation totals on pollen seasons of Ambrosia, Poaceae and Populus in Szeged, southern Hungary. Grana 51: 215-227. doi:10.1080/00 173134.2012.661764.

Mullenders W (1974) Aeropalynological research in Belgium: Atlas of european allergenic pollens (ed. by J Charpin, R Surinyach \& AW Frankland) Sandoz, Paris, pp. 95-102.

Noss RF, LaRoe ET \& Scott JM (1995) Endangered ecosystems of the United States: a preliminary assessment of loss and degradation. USDI National Biological Service, Biological Report 28, Washington D.C.
Oduber F, Calvo AI, Blanco-Alegre C, Castro A, Vega-Maray AM, Valencia-Barrera RM, Fernández-González D \& Fraile R (2019) Links between recent trends in airborne pollen concentration, meteorological parameters and air pollutants. Agricultural and Forest Meteorology 264: 16-26. doi:10.1016/j.agrformet.2018.09.023.

Orlandi F, García-Mozo H, Galán C, Romano B, Díaz de la Guardia C, Ruiz L, Trigo MDM, Dominguez-Vilches E \& Fornaciari M (2010) Olive flowering trends in a large Mediterranean area (Italy and Spain). International Journal of Biometeorology 54: 151-163. doi:10.1007/s00484-0090264-x.

Oteros J, García-Mozo H, Alcázar P, Belmonte J, Bermejo D, Boi M, Cariñanos P, Díaz de la Guardia C, Fernández-González D, González-Minero F, Gutiérrez-Bustillo AM, Moreno-Grau S, PérezBadía R, Rodríguez-Rajo FJ, Ruíz-Valenzuela L, Suárez-Pérez J, Trigo MM, Domínguez-Vilches E \& Galán C (2015) A new method for determining the sources of airborne particles. Journal of Environmental Management 155: 212-218. doi:10.1016/j.jenvman.2015.03.037.

Pawankar R, Holgate ST, Canonica GW, Lockey RF \& Blaiss M (2013) The WAO White Book on Allergy 2013 Update. World Allergy Organization.

Rojo J, Rapp A, Lara B, Fernández-González F \& Pérez-Badia R (2015) Effect of land uses and wind direction on the contribution of local sources to airborne pollen. Science of the Total Environment 538: 672-682. doi:10.1016/j.scitotenv.2015.08.074.

Rousi M \& Heinonen J (2007) Temperature sum accumulation effects on within-population variation and long-term trends in date of bud burst of European white birch (Betula pendula). Tree Physiology 27: 1019-1025. doi:10.1093/treephys/27.7.1019.

Rousi M, Heinonen J \& Neuvonen S (2011) Intrapopulation variation in flowering phenology and fecundity of silver birch, implications for adaptability to changing climate. Forest Ecology and Management 262: 2378-2385. doi:10.1016/j. foreco.2011.08.038.

Rousi M, Possen BJMH, Pulkkinen P \& Mikola J (2019) Using long-term data to reveal the geographical variation in timing and quantity of pollen and seed production in silver and pubescent birch in Finland: Implications for gene flow, hybridization and responses to climate warming. Forest Ecology and Management 438: 25-33. doi:10.1016/j.foreco.2019.02.001.

Rusanen M, Vakkari P \& Blom A (2003) Genetic structure of Acer platanoides and Betula pendula in Northern Europe. Canadian Journal of Forest Research 33: 1110-1115. doi:10.1139/x03-025. 
Schmidt CW (2016) Pollen overload: seasonal allergies in a changing climate. Environmental Health Perspective 124: A70-A75. doi:10.1289/ ehp.124-A70.

Spieksma FTM, Emberlin JC, Hjelmroos M, Jäger S \& Leuschner RM (1995) Atmospheric birch (Betula) pollen in Europe: Trends and fluctuations in annual quantities and the starting dates of the seasons. Grana 34: 51-57. doi:10.1080/00173139509429033.

Taylor LR (1961) Aggregation, variance and the mean. Nature 189: 732-735.

Taylor RAJ (2019) Taylor's power law. Academic Press, London, UK.

Xu X, Riley WJ, Koven CD, Jia G \& Zhao X (2020) Earlier leaf-out warms air in the north. Nature Climate Change 10: 370-375. doi:10.1038/ s41558-020-0713-4.
Zhang Y, Bielory L, Cai T, Mi Z \& Georgopoulos P (2015) Predicting onset and duration of airborne allergenic pollen season in the United States. Atmospheric Environment 103: 297-306. doi:10.1016/j.atmosenv.2014.12.019.

Ziska L, Knowlton K, Rogers C, Dalan D, Tierney N, Elder MA, Filley W, Shropshire J, Ford L B, Hedberg C, Fleetwood P, Hovanky KT, Kavanaugh T, Fulford G, Vrtis RF, Patz JA, Portnoy J, Coates F, Bielory L \& Frenz D (2011) Recent warming by latitude associated with increased length of ragweed pollen season in central North America. Proceedings of the National Academy of Sciences of the USA 108: 4248-4251. doi:10.1073/ pnas.1014107108. 